\title{
Research Paper: Evaluation of Farmers' Resilience Against Socioeconomic Consequences of Drought: A Case Study on Sabzevar, Iran
}

\author{
Alireza Darban-e Astane ${ }^{1 *}$, Ghaazale Azimpour ${ }^{2}$ \\ 1. Assistant Professor, Department of Human Geography, Faculty of Geography, University of Tehran, Tehran, Iran. \\ 2. MA, Department of Human Geography, Faculty of Geography, University of Tehran, Tehran, Iran.
}

\begin{tabular}{l|l}
$\begin{array}{c}\text { Use eour device to scan } \\
\text { and read the article online }\end{array}$ \\
Sequences of Drought: A Case Study on Sabzevar, Iran. Journal of Sustainable Rural Development, 1(1), 27-38. https://doi. \\
org/10.18869/nrip.jsrd.1.1.25
\end{tabular}

Article info:

Received: 04 Jan. 2017

Accepted: 01 Apr. 2017

Keywords:

Resilience, Consequences

of drought, Socioeconomic

consequences, Sabzevar, Iran

\section{ABSTRACT}

Purpose: Rural economy depends substantially on agricultural activities. As Iran is situated on the belt of drought, there is a serious threat for rural economy, and as a consequence a threat for rural persistence and resilience. The current study aimed at evaluating the farmers' resilience against social and economic consequences of drought.

Methods: It was a survey study including all farmer family breadwinners living in Sabzevar, Iran, among which 301 were selected from 14 villages to be studied. Statistical reliability of the social and economic consequences was 0.754 and 0.876 , respectively. Single sample $t$ test was used to evaluate the results of the survey. The study used 57 items and 14 components to assess the consequences of drought.

Results: From the economical point of view, the average value for components of production value, production quality, cost of natural resources (losses), production costs, costs of living, and investment were $2.65,2.08,21.35,31.37,10.22,5.53$, and 2.97, respectively; and from the social point of view, the average value for components of quality of life, poverty, employment, mental stress, reduction of public security, increase of crime, and social damage were 13.12, $9.08,6.01,14.97,8.94,15.40$, and 16.30 , respectively.

Conclusion: The results obtained by $t$ test showed that the studied villages were not resilient against drought. Two general approaches were finally suggested to cope with drought.

\section{Introduction}

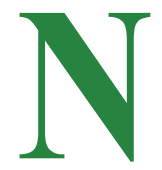

atural and sudden incidents, which bring about problems and destructions in physical, social, and economic capabilities such as casualties and financial losses, are known as natural disasters. Earthquake, floods, droughts, natural pestilence, volcanos, fires, and atmospheric incidents can be mentioned as clear examples in this concern (Owzi, 2011: 3). In recent decades, drought was the most important and harsh one among natural disasters, which influenced the life of human being. Drought starts very slow and its impact appears gradually in a long period of time in various sections

* Corresponding Author:

Alireza Darban-e Astane, PhD

Address: Department of Human Geography, Faculty of Geography, University of Tehran, Azin Alley, Vesal Shirazi St., Enghelab Ave., Tehran, Iran. Tel: +98 (21) 61113793

E-mail: astaneali@ut.ac.ir 
such as water resources, agriculture, society, environmental economy, etc. Identifying its exact time of beginning and ending is somehow difficult, as it is usually described as a creeping phenomenon (Wilhite, 1997: 952).

Since drought comes creeping and intangibly, due to its great expansion, involvement of large population, its loss, and long term economic, social, and environmental consequences, it always raises more attention than any other natural disaster. Drought has 2 hazards: confronting with dangers and vulnerability (Carrão, Naumann, \& Barbosa, 2016: 109). Drought is considered as a catastrophe by itself, yet its impact on human beings and environment decides on being tragic or not. Close relationship between the growth of trees and plants, and climate shows that any changes in climate greatly controls growth pattern. Harsh extreme weather condition with increased drought has a critical role in the growth of plants to take them towards destruction (Natalini, Alejano, Vázquez-Piqué, Cañellas, \& Gea-Izquierdo,, 2016: 53).

Dry weather is a feature of the climate of Iran, and periodical droughts of recent decades increased the difficulties of the country to put it on the verge of water crises. It is, therefore, essential to make a balance between the limitations in water resources and prevailing improvement of the country, which can only be obtained through scientific management of water section (Asadi, Mobin, Malekinejad, Dastourani, \& Rezaee-Zarchi, 2009: 3). Mismanagement of the water resources of the country is worse when it is compared to other countries with similar climates, such as Australia, which is capable of changing the constraints, difficulties, and shortcomings into opportunities for development. Lots of regions in Iran are unfortunately under the influence of severe to very severe drought with great losses in agricultural sector (FatehiMarj \& Heydarian, 2013: 11). Drought has various impacts on the society among which some social elements such as high rate of illiteracy, heavy reliance on climatesensitive jobs, low diversification of income sources, and limited access to climatic change data help the high vulnerability of the regions (Dumenu \& Obeng, 2016: 215).

Sabzevar, in the West of Khorasan Razavi province, is located between the North and South highlands, according to Statistical Center of Iran (2011: 35). Farmers, as the main population of the region, plant pistachio, black cumin, and saffron. Therefore, it can be said that its socioeconomic living deeply depends on precipitation and water resources. A study on this region showed that the hazard of desertification was very high (Silakhori, Oneq, \& Sa'duddin, 2014: 96). Reviews indicated that in many parts of the world, drought management consists of re- sponding to the impacts of drought after happening in the form of crisis management, as untimely, poorly coordinated, and deeply crumbled (Carrão et al., 2016: 116). Various consequences of the multiple droughts and the desertification phenomenon are imposed to the farmers of the region. Therefore, the current study aimed at reviewing the farmers' tolerance against the socioeconomic consequences of drought. In other words, the question is: "Whether the agricultural community of Sabzevar is resilient against social and economic hazards of drought?".

\section{Literature Review}

\section{Resilience}

The word "resilience" is derived from Latin root "resalire" meaning "jump or rise back to previous situation" (Gunderson, Allen, Holling, 2009: 19). The concept has a root in physics and mathematics to define the ability of a material or a system to return to equilibrium position after being relocated or moved. It was first used as a descriptive term in ecology by Haling (known as resilience father) in 1973. Since then the term is widely used in multiple fields including disaster management, psychology, and ecology, with great impacts (Mayunga, 2007: 3).

As hazards are the incidents that threaten societies and their various related areas (economy, culture, etc.), and also the environment, with some undesired consequences, resilience may be considered as a common concept in ecology, sociology, and economy. Davis defined resilience as the capability of societies; physical, social, political, and economic systems; buildings and residences, which can bear the hazards caused by tensions and pressures to get back to previous stable situation, deal with future threats, and confront difficulties (Davis, 2006: 143).

Conceptual approaches for resilience may be categorized into 3 parts: 1) Resilience as sustainability, 2) Resilience as recovery, and 3) Resilience as transition. In the first approach, the meaning of resilience is extracted from ecological studies, which define resilience as the ability of a system to get back to previous situation; the extent of the disturbance a system can bear before changing the position or absorbing it. In the second approach, it is the ability of a society to "return to the past" after a change or a pressure; it is a scale to measure the time a society needs to be recovered, and finally, the approach of transition, which is related to social resilience and community capacity to respond to change, defines it as a change to a new and more sustainable situation, instead of just simple return to past. The current study followed the third approach (Alipour, Chahrsooghi Amin, \& Qarib, 2013: 116). 


\section{Drought}

It is difficult to define drought due to the multiple variables involved in its occurrence. Palmer defines drought as a period in which precipitation, or any other indicator, has negative anomalies compared to average conditions (Roknuddin-Eftekhari, Moosavi, Poortaheri, \& FaradjzadeAsl, 2013: 8). Another idea considers drought as lack of rainfall and increase of temperature, which may happen under any climatic conditions. Climate change is often experienced in 4 environmental areas: irregular rainfall, reduced crop production or yield loss, long periods of drought, and change of harvest season (Dumenu \& Obeng, 2016: 209).

Drought is a complex natural phenomenon, and just 1 indicator does not suffice to describe it in a region (Hao, Hao, \& Singh,, 2016: 110). Regarding its complexity, it is not trustworthy to rely on just 1 indicator (such as SPI, with all its limitations) to forecast it (Carrão et al., 2016: 110). All its aspects should be considered in predicting and responding to it (Dumenu \& Obeng, 2016: 209). Most of the researchers divided drought into 4 types: meteorological, agricultural, hydrological, and socioeconomics (Liu et al., 2016: 755). Meteorological drought is caused by rainfall less than average due to weather conditions of the study area.

Agricultural drought is caused by reduction of soil moisture content to less than the actual needs of plants and crops in a definite period of time that leads to harms (regarding plants physiology and soil physics) (Faradjzade, 2004: 32). Agricultural drought monitoring is done through changing traditional indicators of pure meteorology to scientific meteorology and indicators of monitoring and integrated remote sensing.

Hydrological drought is caused by reduced surface and underground flows (Faradjzade, 2004: 18), not enough to meet regional needs, or total runoff to be less than longterm average runoff. Socioeconomic drought is caused by lack of water to meet the human needs regarding demand and supply dependencies in different time and places, which bring about social and economic anomalies after a long period of meteorological and hydrological droughts resulting in famine, death, and widespread mass migrations. This type of drought has great impact on various aspects of economy, specifically on special types of crops and economic goods (Sobhani-nasab, 2009: 799).

\section{Consequences of drought}

The consequences of drought may be direct or indirect. Though drought is normally accompanied by dry weather, it may happen in any part of the world, even the rainy and wet parts. It deeply influences agricultural section, public and domestic welfare, tourism, ecosystem, and services. Due to the attention paid to socioeconomic consequences of drought, it is known as the most destructive natural disaster all around the world. Harsh climatic conditions, specially the increase of dry weather, may have a role in the function and process of plant mortality (Natalini et al., 2016: 52). There are large serious damages of drought all over the world, which lead to agricultural breakdown and failures, and even famine in some parts of the glob (Hao et al., 2016: 109). The impact of drought on farming, animal husbandry, rural manufacturing and industry, human life style, and residents is sometimes so great that it may cause lack of enough food, and even famine (Hosseini-jenab, Seyyedi, Habibi-Saravi, Jabbari, \& Metani, 2015; Rezaee \& Muhammadi-Yegane, 2013: 154-177).

According to the studies, the highest vulnerability happens to the villages with less experience in responding to long-term droughts, and their socioeconomic structures are not ready to confront such disasters and are mostly dependent on governmental banking facilities for their livelihood and land ownership.

Five elements are mentioned as the effects of drought in some studies: increase of production costs, reduction of wheat production, decline of farmers' income, decrease of farmers' future productivity, and social impacts on the 5 fields influencing the farmers' conditions: social harms, low level of health and nutrition, mental impacts, social disparities, and growth of poverty (Alipour et al., 2013: 115; Chakkoshi, 2001: 3; Nassaji-zavare, 2001: 44-53).

Some studies pay more attention to some social and psychological impacts (adverse health effects such as despair, depression, anger, sadness, discouragement, reduction of social contributions, and reduced social relations; creation of social conflict such as arguments, loss of credibility, and immigration). However, some other studies indicated that economic impacts (reduced income; raised unemployment; increased costs; decreased income from crop production and livestock; decreased quality of production, and loss of most of it) seriously influenced stockbreeding activities in the region to reduce production. Increased prices, changes in utilization systems, increased production costs, lowered rural asset values, decreased current, and fixed assets of rural households are among the most emphasized factors (Rezaee \& MuhammadiYegane, 2013: 155; Fatemi \& Karami, 2010: 10; Salim, 2008: 92, 89-124) that their continuation causes changes in rural function and results in migrations (Muhammadi- 


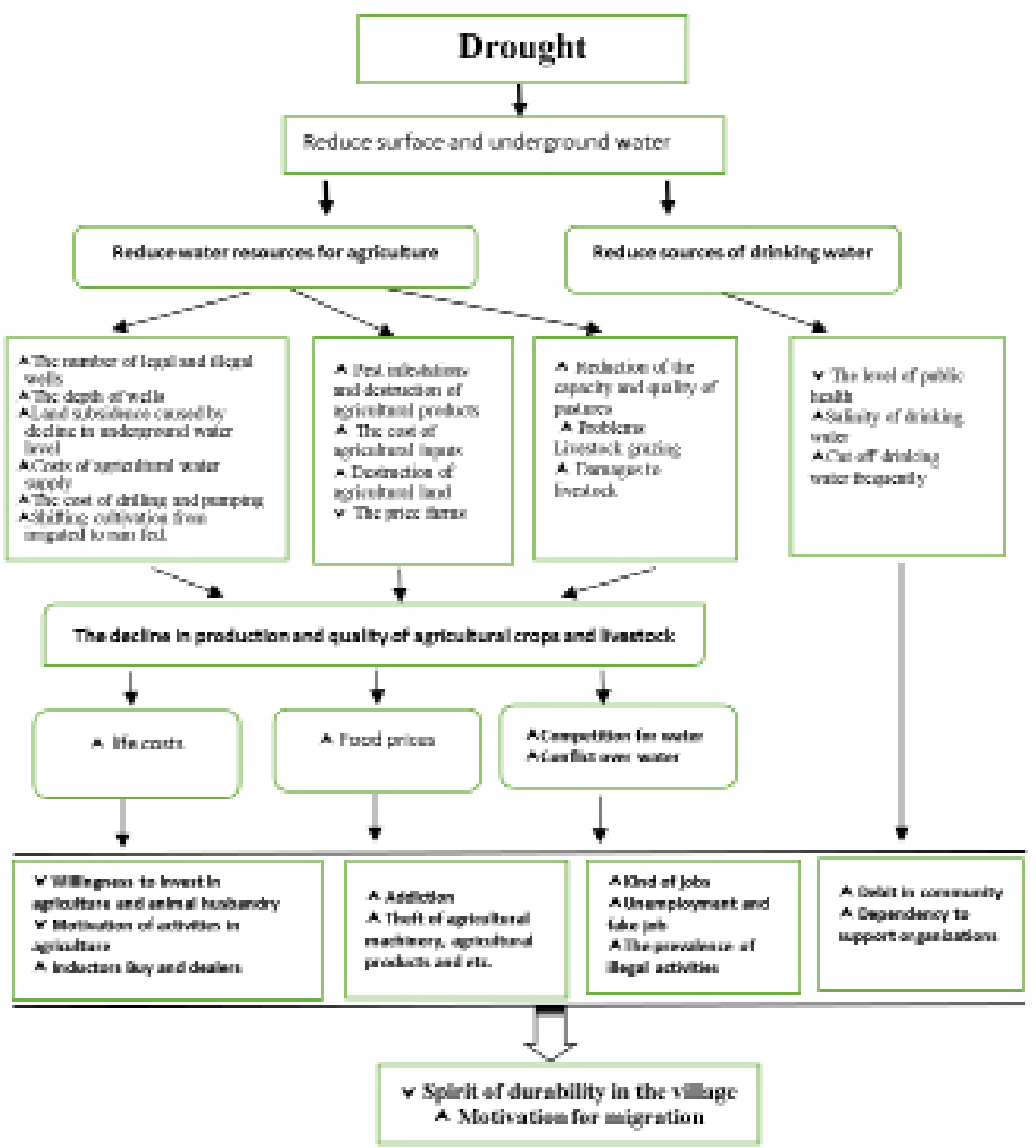

Figure 1. Conceptual model of the study

Yegane \& Hakimdoost, 2009: 2). Furthermore, environmental problems, decreased quality, and the quantity of production are among the reported consequences mentioned by the researchers (Mojaverian, Ahmadi-Kaliji, \& Ravan, 2015; Natalini et al, 2016; Dumenu \& Obeng, 2016; Hao et al, 2016; Carrão et al, 2016; Liu et al., 2016). The socioeconomic consequences of drought may be summarized as the following diagram (Figure 1).

\section{Methodology}

It was an applied research; because it was used for the resilience theories and evaluation to get familiar with so- cioeconomic consequences of drought in Sabzevar, and its findings were used to reduce negative consequences. According to its nature and methodology, the current study was on how and why the resilience, drought, and their different dimensions are so important, and also to use the findings to lower the negative consequences. The analysis considered the existing situation and evaluated the relationship among different variables; therefore, it was a cross sectional descriptive study. The statistical population included all heads of Sabzevar farmer families who lived in villages during the period of the study (in 2015). In Figure 2 Map showing the geographical location of the study area. According to 2011 capitation, the 


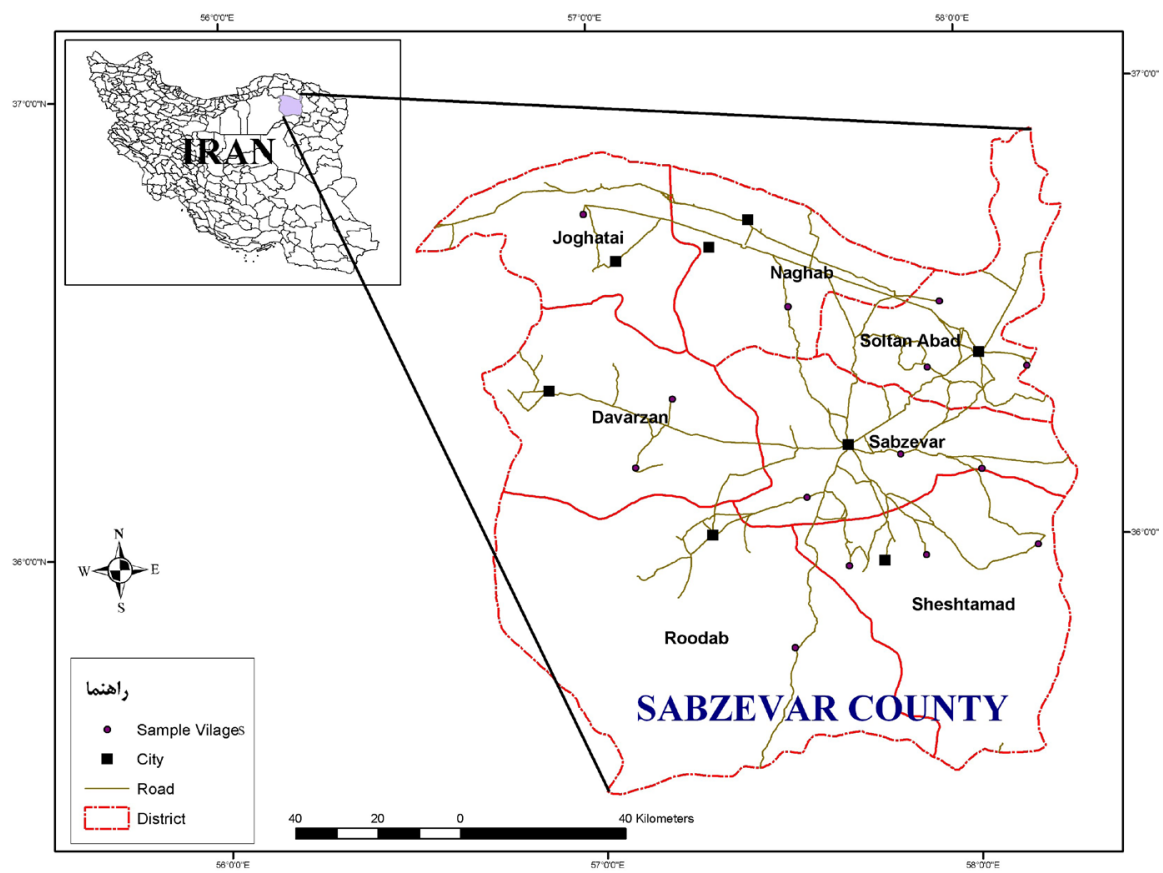

Figure 2. Geographical location of the study area

total number of farmers in the whole rural population was $58 \%$ or 10480 families, according to Statistical Center of Iran, 2011. Accordingly, the analytic unit was considered an individual person. Cochran formula was used to calculate the population size as: $\mathrm{z}=1.96$ by $95 \%$ Confidence Interval (CI); deviation, 3.32; half statistical accuracy (d), 0.36 ; hence, the sample size was assessed 301.

Respondents in the study were randomly selected. A total of 14 villages were randomly selected and, then, questioned. The villages were Za'ferania, Kheyrabad, Abaresh, Kalate Arab, Delqand, Keizor, Fasonqor, Keizoqan, Baqajar, Salihabad, Kal Khuni, Balashabad, Shari, and Delbar.

The 28 variables in 7 components used to review social consequences were as follows: quality of life, poverty or income, employment, psychological tensions, public safety, crime and delinquency, and social damage. There were also 29 variables in 7 components to evaluate economic consequences: amount of production, quality of production, costs of natural resources (losses), production costs, costs of living, overall level of living, and investment. Socioeconomic consequences were modeled in a 5-point Likert Scale.

The validity of the questionnaire was confirmed in a piloTtest by the cooperation of some faculties and researchers. The reliability of the socioeconomic scales for socioeconomic consequences were 0.754 and 0.876 , respectively. Single-sample T-test was used to assess the results of the test.

\section{Findings}

Economic consequences of drought

Villagers were asked to give their ideas about the level of drought impacts according to 29 economic variables, obtained from previous studies. Seven components of the amount of production, quality of production, costs of natural resources (losses), production costs, costs of living, overall level of living, and investment, with their variables were studied according to the impacts of drought on rural family economy in the studied area and summarized as follows:

\section{Amount of production}

One of the consequences deduced from drought is reduction of production and consequently reduction of farmers' income. Respondents' views showed that agricultural products reduced by $64.5 \%$ and livestock production by $57.5 \%$ (just to meet the rural family needs).

\section{Quality of production}

Respondents believed that there were changes in the quality of agricultural production (47.5\% reduction) and livestock production (64.5\% reduction) due to the extended period of deficient precipitation, and following water and food scarcity. 
Costs of natural resources (losses)

According to respondents, agricultural needed water reduced by $96.5 \%$, which was considered critical. Wind erosion increased by $71.5 \%$, which was harsh. The number and depth of legal and illegal wells increased by $87 \%$, change of irrigated farms to rainfed ones by $78.5 \%$, destruction of agricultural lands by $78.6 \%$, and abandoned farmlands by $70 \%$.

At the same time, the damage to the herders confronted with harsh reduction of $100 \%$ and $82.5 \%$ for the quantity and quality of pastures, respectively.

Table 1. The impact of drought on economy, according to the respondents viewpoints

\begin{tabular}{|c|c|c|c|c|c|c|c|}
\hline Component & Items & $\begin{array}{l}\text { d. De- } \\
\text { creased }\end{array}$ & $\begin{array}{l}\text { De- } \\
\text { creased }\end{array}$ & $\begin{array}{c}\text { No } \\
\text { Change }\end{array}$ & $\begin{array}{l}\text { In- } \\
\text { creased }\end{array}$ & $\begin{array}{l}\text { d. In- } \\
\text { creased }\end{array}$ & $\begin{array}{l}\text { Aver- } \\
\text { age }\end{array}$ \\
\hline \multirow{2}{*}{ Amount of production } & Amount of crops & 31.0 & 64.5 & 4.5 & 0.0 & 0.0 & 1.74 \\
\hline & Amount of livestock production & 27.1 & 57.8 & 11.1 & 4.0 & 0.0 & 1.91 \\
\hline \multirow{2}{*}{ Quality of production } & Quality of crops & 23.0 & 64.5 & 11.5 & 1.0 & 0.0 & 1.88 \\
\hline & Quality of livestock production & 19.5 & 47.5 & 30.5 & 2.5 & 0.0 & 1.58 \\
\hline \multirow{8}{*}{$\begin{array}{l}\text { Costs of natural re- } \\
\text { sources (losses) }\end{array}$} & Wind erosion & 0.0 & 0.0 & 28.5 & 27.0 & 44.5 & 4.16 \\
\hline & Farmland destruction & 0.0 & 0.0 & 21.6 & 59.8 & 18.6 & 3.98 \\
\hline & Amount of water needed for farming & 45.5 & 51.0 & 2.5 & 0.5 & 0.5 & 1.60 \\
\hline & $\begin{array}{c}\text { Number and depth of legal and illegal } \\
\text { wells }\end{array}$ & 0.0 & 0.5 & 12.5 & 52.0 & 35.0 & 4.22 \\
\hline & Change of irrigated farms to rainfed & 0.0 & 0.0 & 21.5 & 66.0 & 12.5 & 3.19 \\
\hline & Abandoned farmlands & 0.5 & 0.5 & 29.0 & 51.5 & 18.5 & 3.87 \\
\hline & Quantity of pastures & 51.0 & 49.0 & 0.0 & 0.0 & 0.0 & 1.49 \\
\hline & Quality of pastures & 46.5 & 46.5 & 7.5 & 0.5 & 0.0 & 1.62 \\
\hline \multirow{10}{*}{ Production costs } & $\begin{array}{l}\text { Land subsidence caused by under- } \\
\text { ground water loss }\end{array}$ & 0.0 & 0.0 & 51.0 & 43.0 & 6.0 & 3.55 \\
\hline & Price of grazing livestock & 0.5 & 1.5 & 4.0 & 71.5 & 22.5 & 4.17 \\
\hline & Damages to livestock & 0.0 & 0.5 & 9.0 & 68.0 & 22.5 & 4.15 \\
\hline & $\begin{array}{c}\text { Costs of drilling and pumping of } \\
\text { groundwater }\end{array}$ & 0.0 & 0.0 & 13.5 & 62.5 & 24.0 & 4.22 \\
\hline & $\begin{array}{c}\text { Costs of agricultural inputs (seed, } \\
\text { fertilizer, etc.) }\end{array}$ & 0.0 & 0.0 & 4.5 & 65.5 & 30.0 & 4.30 \\
\hline & Costs of agricultural water supply & 0.0 & 0.0 & 2.5 & 60.5 & 37.0 & 4.35 \\
\hline & Value of farmlands & 27.5 & 40.0 & 5.5 & 23.5 & 3.5 & 2.36 \\
\hline & Excavating the depth of wells & 2.5 & 4.5 & 24.5 & 55.5 & 13.0 & 3.86 \\
\hline & $\begin{array}{l}\text { Pest infestations and destruction of } \\
\text { crops }\end{array}$ & 0.0 & 0.0 & 17.5 & 36.5 & 46.0 & 4.34 \\
\hline & Speculative short selling & 0.0 & 3.5 & 62.5 & 32.0 & 2.0 & 3.40 \\
\hline \multirow{2}{*}{ Costs of living } & Non-food expenditure & 0.0 & 0.0 & 0.5 & 50.0 & 49.5 & 4.49 \\
\hline & Food expenses & 0.0 & 0.0 & 0.0 & 44.5 & 55.5 & 4.56 \\
\hline \multirow{3}{*}{ Overall level of living } & Salinity of drinking water & 2.5 & 12.6 & 50.3 & 34.2 & 0.5 & 3.18 \\
\hline & Amount of drinking water & 31.0 & 52.5 & 16.0 & 0.5 & 0.0 & 1.78 \\
\hline & Job diversity & 0.0 & 42.5 & 46.0 & 11.5 & 0.0 & 2.69 \\
\hline \multirow{2}{*}{$\begin{array}{l}\text { Production investment } \\
\text { willingness }\end{array}$} & Agricultural investment & 26.5 & 49.0 & 19.5 & 5.0 & 0.0 & 2.03 \\
\hline & Livestock investment & 31.5 & 50.5 & 16.0 & 2.0 & 0.0 & 1.89 \\
\hline
\end{tabular}




\section{Production costs}

Respondents believed that the costs of agricultural water supply increased by $97.5 \%$, the costs of agricultural inputs (seed, fertilizer, etc.) by $95.5 \%$, costs of drilling and pumping of groundwater by $86.5 \%$, exca- vating the depth of wells by $68.5 \%$, pest infestations and destruction of crops by $82.5 \%$, damages to livestock by $90.5 \%$, and speculative short selling by $34 \%$. On the other hand, the value of farmlands was harshly decreasing by $67.5 \%$, which resulted in poor or even

Table 2. The average of the impacts of drought on society, according to the respondents

\begin{tabular}{|c|c|c|c|c|c|c|c|}
\hline Component & Items & $\begin{array}{l}\text { d. De- } \\
\text { creased }\end{array}$ & $\begin{array}{l}\text { De- } \\
\text { creased }\end{array}$ & $\begin{array}{l}\text { No } \\
\text { Change }\end{array}$ & $\begin{array}{c}\text { In- } \\
\text { creased }\end{array}$ & $\begin{array}{l}\text { d. In- } \\
\text { creased }\end{array}$ & $\begin{array}{l}\text { Aver- } \\
\text { age }\end{array}$ \\
\hline \multirow{4}{*}{ Quality of life } & Decreased levels of health and sanitation & 0.5 & 10.5 & 19.5 & 35.5 & 34.0 & 4.14 \\
\hline & Reduced recreational opportunities & 0.0 & 0.5 & 43.0 & 50.5 & 17.0 & 3.84 \\
\hline & Frequent repetitive water cut & 0.0 & 0.5 & 9.0 & 31.5 & 59.0 & 4.57 \\
\hline & Declination of quality of life & 0.0 & 1.0 & 16.0 & 71.0 & 12.0 & \\
\hline \multirow{3}{*}{$\begin{array}{l}\text { Poverty or } \\
\text { income }\end{array}$} & Financial debt & 0.0 & 0.5 & 29.0 & 38.5 & 32.0 & 4.03 \\
\hline & Villagers' dependency to welfare institutes & 0.0 & 0.0 & 18.5 & 59.5 & 22.0 & 4.04 \\
\hline & Reduction of social role of local people & 0.0 & 0.0 & 32.0 & 65.5 & 2.5 & 3.72 \\
\hline \multirow{15}{*}{ Employment } & Pseudo-jobs & 0.0 & 7.5 & 68.0 & 24.0 & 0.5 & 3.31 \\
\hline & Joblessness in villages & 0.5 & 0.5 & 11.0 & 41.5 & 46.5 & 4.37 \\
\hline & Willingness to persistent life in the village & 0.0 & 60.0 & 14.5 & 4.0 & 0.0 & 2.00 \\
\hline & Depression & 0.0 & 1.0 & 37.0 & 62.0 & 0.0 & 3.63 \\
\hline & Suicide & 0.0 & 0.5 & 91.0 & 8.5 & 0.0 & 3.8 \\
\hline & Refusing farming and ranching & 0.0 & 0.5 & 30.0 & 57.5 & 12.0 & 3.81 \\
\hline & Migration motivations & 0.0 & 8.5 & 23.0 & 30.5 & 38.0 & 4.06 \\
\hline & Competitions on water & 0.5 & 0.5 & 24.0 & 46.5 & 28.5 & 4.24 \\
\hline & Increased conflicts on water resources & 0.0 & 3.0 & 42.5 & 53.5 & 1.0 & 3.60 \\
\hline & Blackmailing in villages & 0.0 & 1.0 & 27.0 & 51.0 & 21.0 & 3.93 \\
\hline & Farming equipment theft & 0.0 & 1.5 & 53.5 & 42.0 & 3.0 & 3.55 \\
\hline & Burglary & 0.0 & 5.5 & 34.5 & 49.0 & 11.0 & 3.78 \\
\hline & Crop stealing & 0.0 & 0.5 & 38.0 & 45.0 & 16.5 & 3.81 \\
\hline & Livestock stealing & 0.0 & 0.5 & 49.5 & 48.0 & 2.0 & 3.62 \\
\hline & $\begin{array}{l}\text { Prevalence of illegal activities and smug- } \\
\text { gling }\end{array}$ & 0.5 & 0.5 & 76.0 & 23.0 & 0.0 & 3.27 \\
\hline \multirow{6}{*}{ Social damage } & Divorce & 0.0 & 0.5 & 76.5 & 17.0 & 6.0 & 3.30 \\
\hline & Dropout & 0.0 & 4.0 & 2.0 & 49.5 & 44.5 & 4.42 \\
\hline & Addiction & 0.0 & 3.0 & 43.0 & 36.0 & 18.0 & 3.73 \\
\hline & Family coherence & 0.0 & 38.5 & 44.5 & 15.5 & 1.5 & 2.57 \\
\hline & Rural family unity & 0.0 & 47.5 & 44.5 & 8.0 & 0.0 & 2.58 \\
\hline & Marriage & 22.5 & 64.5 & 9.5 & 3.5 & 0.0 & 1.85 \\
\hline
\end{tabular}


Table 3. The role of drought in economic parameters, according to the T-test

\begin{tabular}{|c|c|c|c|c|c|c|}
\hline Economic Components & T-Test Value & Average & $\begin{array}{l}\text { Difference } \\
\text { Average }\end{array}$ & $\begin{array}{l}\text { Level of Signifi- } \\
\text { cance }\end{array}$ & Upper Limit & Lower Limit \\
\hline $\begin{array}{l}\text { Amount of agricultural } \\
\text { production }\end{array}$ & 39.326 & 4.17 & 1.07 & 0.00 & 0.78 & 0.96 \\
\hline $\begin{array}{l}\text { Quality of agricultural } \\
\text { production }\end{array}$ & 41.301 & 4.27 & 1.17 & 0.00 & 1.39 & 1.52 \\
\hline $\begin{array}{c}\text { Cost of natural resources } \\
\text { (losses) }\end{array}$ & 33.472 & 4.08 & 0.98 & 0.00 & 3.7 & 5.3 \\
\hline Cost of production & 33.499 & 4.04 & 0.94 & 0.00 & 0.92 & 1.09 \\
\hline Cost of life & 45.793 & 4.2 & 1.1 & 0.00 & 1.08 & 1.23 \\
\hline $\begin{array}{c}\text { Overall life level declina- } \\
\text { tion }\end{array}$ & 20.432 & 3.57 & 0.47 & 0.05 & 1.17 & 1.32 \\
\hline Investigation & 38.463 & 4.04 & 0.94 & 0.00 & 1.32 & 1.46 \\
\hline
\end{tabular}

none economic efficiency of involvement in farming and ranching.

\section{Costs of living}

Due to the average views of respondents, non-food expenditure of rural household costs increased by $99.5 \%$ and food expenses by $100 \%$ along with increasing costs of production.

\section{Overall level of living}

Respondents announced that drinking water became $34.7 \%$ more saline, and the amount of it decreased by $82.5 \%$; job diversity also reduced by $42.5 \%$.

\section{Investment}

Regarding the negative impacts of drought on economy, based on agriculture and livestock, the respondents believed in $75.5 \%$ and $81.5 \%$ reduction in the investment. The detailed information was presented in Table 1.

\section{Social consequences of drought}

Villagers were asked to give their ideas about the level of drought impacts according to 28 social variables, obtained from previous studies. Seven components of quality of life, poverty or income, employment, psychological tensions, public safety, crime and delinquency, and social damage along with their variables were studied, according to the impacts of drought on rural family economy in the studied area and summarized as follows:

\section{Quality of life}

Regarding the rural household quality of life, respondents believed that the level of health and sanitation, recreational opportunities, repetitive and frequent water cut, and total life quality had a great decrease by $69.5 \%$, $67.5 \%, 89.5 \%$, and $83 \%$, respectively, among which repetitive and frequent water cut was the worst.

\section{Poverty or income}

Respondents considered increases in financial debts in the society by $70.5 \%$, villagers' dependency on welfare organizations by $81.5 \%$, and a decrease in the social role of the local people by $68 \%$.

\section{Employment}

Respondents believed that pseudo-jobs increased by $24.5 \%$, and unemployment by $88 \%$ in the studied area.

\section{Psychological tensions}

Respondents explained the spirit of continuing life in the villages reduced by $81.5 \%$, and on the contrary, depression increased by $62 \%$, suicide by $8.5 \%$, refusing farming and ranching by $69.5 \%$, and motivations for migration by $68.5 \%$.

\section{Public safety}

Respondents considered competition for water, conflicts for water resources, and blackmail endangered the safety of villagers, which increased by $75 \%, 54.5 \%$, and $72 \%$, respectively. 
Table 4. The role of drought in social factors, according to T-test

\begin{tabular}{|cccccccc}
\hline Social Components & $\begin{array}{c}\text { T-Test Statis- } \\
\text { tics }\end{array}$ & Average & Mean Difference & Level of Significance & Upper Limit & $\begin{array}{c}\text { Lower } \\
\text { Limit }\end{array}$ \\
\hline Quality of life & 45.442 & 4.29 & 1.19 & 0.00 & 0.5 & 0.74 \\
\hline Poverty or income & 25.431 & 3.93 & 0.83 & 0.00 & -0.03 & 0.18 \\
\hline Employment & 21.586 & 3.84 & 0.74 & 0.00 & 0.95 & 1.10 \\
\hline Psychological tension & 24.784 & 3.86 & 0.76 & 0.00 & 0.96 & 1.12 \\
\hline Public safety & 25.231 & 3.92 & 0.82 & 0.00 & 0.65 & 0.83 \\
\hline Crime and delinquency & 12.363 & 3.60 & 0.5 & 0.00 & 0.40 & 0.71 \\
\hline Social damage & 14.706 & 3.78 & 0.68 & 0.00 & 1.12 & 1.38 \\
\hline
\end{tabular}

\section{Crime and delinquency}

According to the respondents, farming equipment theft increased severely by $43 \%$, burglary by $60 \%$, crop stealing by $61.5 \%$, livestock stealing by $50 \%$, and prevalence of illegal activities and smuggling by $23 \%$.

\section{Social damage}

Respondents indicated that divorce increased by $23 \%$, educational failure and dropout among the youth by $94.5 \%$, and addiction by $54 \%$ among the villagers, and on the other hand, family unity decreased by $47.5 \%$, and marriage by $86.5 \%$.

\section{Evaluation of the economic consequences of drought}

To evaluate the economic consequences of drought, first the date were collected. After calculating the average composition of items in each component, data were analyzed by the single-sample T-test. Findings are indicated in Table 3.

The averages of production quantity and quality component were 4.17 and 4.27, respectively; and T-test results showed significance of the test with $95 \% \mathrm{CI}$. As the average was negative, it can be said that drought caused reduction in production quantity and quality. For components related to cost of natural resources (losses), pro- duction costs, costs of living, and overall level of living with average values of $4.08,4.04,4.02$, and 3.57 respectively, T-test was in the significant level of $99 \%$. With regard to the positive difference of calculated average and the given number, it can be said that drought increased the costs of natural resources (losses), costs of crops and livestock productions, life expenses, and declination of overall level of life in recent decades. This result was also true for reduction of investment. The detailed information was presented in Table 2.

\section{Evaluation of the social consequences of drought}

The effect of drought was studied in all 7 components. The results of one-sample t-test, according to the 5-point Likert scale, were different and showed the effect of drought on the component of quality of life with the mean and $t$ values of 4.29 and 45.442 , respectively; those values were more than those of the test limitation (3.1) (Table 4.).

The component of poverty with the mean and $t$ values of 3.93 and 25.43 of the population, respectively was much higher than that of the test limitation. The component of employment showed the mean and t values of 3.84 and 21.58 , respectively; the mean was above the test limitation value. With regard to the increase in psychological tension, decrease in public safety, and increase in crime and social damage, they had the respective aver-

Table 5. The effect of drought on socioeconomic parameters using T-test

\begin{tabular}{cccccccc}
\hline Components & T-Test Value & Mean & Mean Difference & Level of Significance & $\begin{array}{c}\text { Upper } \\
\text { Limit }\end{array}$ & $\begin{array}{c}\text { Lower } \\
\text { Limit }\end{array}$ \\
\hline Economic & 24.12 & 3.89 & 84.12 & 0.00 & 1.15 & 2.18 \\
Social & 43.2 & 4.12 & 94.10 & 0.00 & 2.78 & 4.25 \\
\hline
\end{tabular}


age values of 3.86, 3.92, 3.60, and 3.78, and respective $\mathrm{t}$ values of $24.78,25.23,12.36$, and 14.70; all averages were above the level of test limitation.

\section{Evaluating resilience against drought}

The effect of drought on social dimension with the mean and $t$ values of 4.12 and 43.2 was more than those of economic dimension with the mean and t values of 3.89 and 24.12, respectively (Table 5).

The first consequence of drought that comes to mind is its economic aspect. However, the current study showed that the worst negative consequences of drought were from social aspect, and the economic one comes after that, in the second place. From this point of view, decreasing quality of life was considered the most important factor that revealed itself in reduced level of health and sanitation, water cut, and reduced opportunities for recreations. On the other hand, it led to reduced level of income and prevalence of poverty in the society. Yet, it is not possible to ignore delinquency and, consequently, the reduced sense of public safety and the psychological stresses following it.

All these showed the severe and critical impacts of drought on the life of people, which changed, during the whole history of mankind, the brave villagers to weak, hopeless people with no confidence, full of fear for their future, and fully dependent on welfare institutes. Therefore, they are driven to migrate to the cities to supply their lives; yet, with not enough proficiency for city life, they are mostly pushed to live in city outskirts; and leaving the villages to the older farmers ( 50 to 60 years old) with less educability and more interests in using old methods of farming instead of new ones. From the economic point of view, expansion of drought causes reduced levels of production and decreased qualities which in turn, bring about less income and lowered levels of production quality and quantity, and as a result higher expenses for living. Increasing costs of production and decreasing production quality and quantity lessen the willingness of investors to enter this field, which was in line with the results of the current study.

\section{Discussion}

The findings of the current study approved the negative effects of drought on socioeconomic dimensions considered for the rural communities. According to some local authorities, in some parts, more than 15 villages are abandoned by 10 years; and drought stress is beyond the capacity of the villagers. From the social aspect, the obtained results showed that the quality of life, employment, and public safety had a harsh decline, but poverty, social damages, crime, and psychological tensions increased.

The obtained results of the current study were mostly consistent with the findings of other studies. From social aspect, they approved the findings by Rezaee \& Muhammadi-Yegane (2013), Fatemi \& Karami (2010), Salim (2008), Muhammadi-Yegane \& Hakimdoost et al. (2009), Natalini et al. (2016), Dumenu \& Obeng (2016), Hao et al. (2016), Carrão et al. (2016), and from the economic view, with those of Alipour et al. (2013), Chakkoshi (2001), and Nassaji-zavare (2001).

Studies show that the drought is getting more severe and lasting. Though avoiding it by human knowledge of today seems impossible, it is surely possible to reduce the hazards of its negative consequences by better understanding of its concepts and effects on different aspects of rural life, and by appropriate monitoring and good programing for hazard management. The first step in confronting with this phenomenon to reduce its harsh negative impacts is to study, recognize and understand the impacts that this phenomenon may bring to vulnerable areas. The current study was accordingly planned and implemented. Due to the limitation of water resources, there are totally 2 approaches to be considered and discussed.

The first approach involves increasing the productivity of existing water resources through modern irrigation methods such as sprinkler irrigation and drip, which needs investment and facilities granted by executive organizations from one side, and mass production of those equipment and selling them to the farmers in fare prices from the other side. In this way, professional changes in cropping patterns from those in need of great amounts of water to those with fewer needs are one of the key methods to fight drought. The current study findings showed that despite the successful efforts in this field, specifically cultivating gardens such as pistachios, instead of vegetables did not bring significant changes in the region.

The second looks for rural business diversification, and changing from farming to services and industry sectors. Due to its good geographical situation, proper distance to Mashhad, and being located in the transit transport corridor, Sabzevar has a nice opportunity to improve its industry sector.

\section{Acknowledgements}

This research did not receive any specific grant from funding agencies in the public, commercial, or not-for-profit sectors. 


\section{Conflict of Interest}

The authors declared no conflict of interests.

\section{References}

Alipour, H., Chahrsooghi Amin, H., \& Qarib, A. (2013). [Effects of drought on socio-economic status of farmers: A case study on the Nehbandans wheat farmers (Persian)]. Watershed Studies (Research and Construction), 99, 115-145

Asadi, M. A., Mobin, M. H., Malekinejad, H., Dastourani, M. T., \& Rezaee-Zarchi, S. (2009). [The effect of climatic factors on the accuracy of artificial neural network-based prediction of drought in the region of Yazd (Persian)]. Paper presented at $5^{\text {th }}$ National Conference on Watershed Management Engineering of Iran, Karaj, Iran, 22-23 April 2009.

Beik Mohamadi, H., Noori, H., Bazrafshan, J. (2006). [Impacts of 1998-2004 droughts on rural economy of Iran's Sistan and its Solutions (Persian)]. Geography and Development Iranian Journal, 3(5), 54-72.

Carrão, H., Naumann, G., \& Barbosa, P. (2016). Mapping global patterns of drought risk: An empirical framework based on sub-national estimates of hazard, exposure and vulnerability. Global Environmental Change, 39, 108-124. doi: 10.1016/j.gloenvcha.2016.04.012

Chakkoshi, B. (2001). [A review of environmental aspects of drought and flood (Persian)]. Paper presented at The First Conference of Examining Ways of Dealing with Water Crisis, Zabol, Iran, 18-19 March 2002.

Davis, M. (2006). Bridging the gap or crossing a bridge? Indigenous knowledge and the language of law and policy. In W. V. Reid, F. Berkes, T. J. Wilbanks, \& D. Capistrano, editors. Bridging Scales and Knowledge Systems: Concepts and Applications in Ecosystem Assessment (pp. 145-163). Washington, D.C. Island Press.

Dumenu, W. K., \& Obeng, E. A. (2016). Climate change and rural communities in Ghana: Social vulnerability, impacts, adaptations and policy implications. Environmental Science $\mathcal{E}$ Policy, 55, 208-217. doi: 10.1016/j.envsci.2015.10.010

Faradjzade, M. (1995). [Drought prediction and analysis in Iran (PhD thesis) (Persian)]. Tehran: Tarbiat Modarres University.

Faradjzade, M. (2004). [Drought from concept to strategy (Persian)] Tehran: Armed Forces Geographical Organization Press.

Farajzade, M. (2013). [Climate risks of Iran (Persian)]. Tehran: Samt.

Fatehi-Marj, A., \& Heydarian, S. A. (2013). [A review of hydrological, agricultural, and metrological drought in Khuzestan using GIS (Persian)]. Iran-Watershed Management Science \& Engineering, 7(23), 9-32.

Fatemi, M., \& Karami, E. (2010). [Analytical case study of causes and effects of drought (Persian)]. Iranian Agricultural Promotion and Education Sciences, 6(2), 77-96.
Gunderson, L. H., Allen. C. R. Holling, C. S. (2009). Foundations of Ecological Resilience. Washington D. C.: Island Press.

Hao, Z., Hao, F., \& Singh, V. P. (2016). A general framework for multivariate multi-index drought prediction based on Multivariate Ensemble Streamflow Prediction (MESP). Journal of Hydrology, 539, 1-10. doi: 10.1016/j.jhydrol.2016.04.074

Hosseini-Jenab, V., Seyyedi, M. D., Habibi-Saravi, R., Jabbari, F., \& Metani, S, (2015). [Disaster hazards (Persian)]. Tehran: Rooyanpazhooh Press.

Khoshakhlaq, F. (1998). [An investigation of Iran comprehensive drought using synoptic analysis (Persian)] [MSc. Thesis]. Tabriz: Tabriz University.

Linsely, R. K., Kolher, M. A., \& Paulhus, J. L. H. (1975). Hydrology for engineers. New York: McGraw-Hill Book Company.

Liu, X., Zhu, X., Pan, Y., Li, S., Liu, Y., \& Ma, Y. (2016). Agricultural drought monitoring: Progress, challenges, and prospects. Journal of Geographical Sciences, 26(6), 750-767. doi: 10.1007/s11442-016-1297-9

Mafakheri, O. (2012). [Determining drought by NDVI Index, and its relation to the changes of surface waters in Qorve and Dehgalan plain (Persian)] [MSc. thesis]. Tehran: Shahid Beheshti University.

Mayunga, J. (2007). Understanding and applying the concept of community disaster resilience: A capital-based approach. Megacities: Social vulnerability and resilience building. Munich, Germany. Paper presented at The Summer Academy for Social Vulnerability and Resilience building, Munich, Germany, 22-28 July 2007.

Mojaverian, M., Ahmadi-Kaliji, A., \& Ravan, M. (2015). [Applying Ricardian approach to investigating climate change on farmland rent (Persian)]. Iranian Agricultural Development and Economic Studies, 46(2), 481-491.

Muhammadi-Yegane, B., \& Hakimdoost, Y. (2009). [Economic impacts of drought and its effects on rural instability, case study: Upper Qara-Poshtloo (Persian)]. Paper presented at (Persian)]. Paper presented at $5^{\text {th }}$ National Conference on $\mathrm{Wa}$ tershed Management Engineering of Iran, Karaj, Iran, 22-23 April 2009.

Nassaji-Zavare, M. (2001). [A review of environmental socioeconomic impacts of drought (Persian)]. Paper presented at The $1^{\text {st }}$ International Conference in Water Crisis, Zabol, Iran, 10 March 2009.

Natalini, F., Alejano, R., Vázquez-Piqué, J., Cañellas, I., \& GeaIzquierdo, G. (2016). The role of climate change in the widespread mortality of holm oak in open woodlands of Southwestern Spain. Dendrochronologia, 38, 51-60. doi: 10.1016/j dendro.2016.03.003

Owzi, R. (2011). [Geography of hazards (Natural and human hazards) (Persian)]. Tabriz: Tabriz University Press.

Palmer, W. C. (1965). Meteorological drought, Research paper 45 Washington D.C.: Weather Bureau.

Poortaheri, M., Eftekhari, A., \& Kazemi, N. (2013). [The role of drought hazard management in reducing socio-economy vulnerability of farmers (from authorities and experts' point of view), case study of Sulduz District of West Azerbaijan (Persian)]. Journal of Rural Research, 4(1), 7-13. 
Rezaee, H., \& Muhammadi-Yegane, B. (2013). [An analysis of drought and its impacts on agro-economy and rural migration (Case study: Abarkooh District in 1996-2005) (Persian)]. Journal of Rural Study and Planning, 4, 154-177.

Riebsame, W. E., Chagnon. S. A., \& Karl, T. R. (1992). Drought and natural Resources management in the United States. Impact and implications of the 1987-1989 drought. Boulder, Colorado: Westview Press.

Roknuddin-Eftekhari, A., Moosavi, M., Poortaheri, M., \& Faradjzade-Asl, M. (2013). [Analysis of livelihood diversification in rural families during drought, case study: Regions under the risk of drought in Isfahan (Persian)]. Journal of Rural Studies, 5(3), 629-662.

Salim, J. (2008). [The impact of drought on nomadic life process of Taheri tribe in Tabas District (Persian)]. Village \& Development, 11(4), 89-124.

Silakhori, I., Oneq, M., \& Sa'duddin, A. (2014). [Evaluating desertification hazard and risk in the region of Sabzevar by using MICD model (Persian)]. Hazard Management, 5, 89-99.

Smit, K. (2000). [Assessment risk and reduction disasters, environmental hazards (Persian)]. London: Routledge.

Sobhani-nasab, Y. (2009). [Socio-economic environmental impacts of drought, Regional Conference of Water and Drought Crisis (Persian)]. Rasht: Islamic Azad University of Rasht.

Statistical Center of Iran. (2011). [Census of population and housing (Persian)]. Tehran: Statistical Center of Iran.

Wilhite, D. A. (1997). Responding to drought: Common threads from the past, visions for the future. Journal of the American Water Resources Association, 33(5), 951-959. doi: 10.1111/ j.1752-1688.1997.tb04116.x

Wipple, W. (1992). Regional drought frequency analysis. Proceedings of the American Society of Civil Engineers, 92(2), 11-13. 